\title{
Voltammetric determination of wedelolactone, an anti-HIV herbal drug, at boron-doped diamond electrode
}

\author{
SACHIN SAXENA, RATNANJALI SHRIVASTAVA and SOAMI P SATSANGEE* \\ USIC, Dayalbagh Educational Institute, Dayalbagh, Agra 282 005, India \\ e-mail: deiusic@gmail.com
}

MS received 27 January 2014; revised 13 December 2014; accepted 23 December 2014

\begin{abstract}
Boron-doped diamond electrode has been utilized for the study of electrochemical behaviour of an anti-HIV herbal drug wedelolactone in Britton-Robinson buffer ( $\mathrm{pH}-2.5)$ by square-wave and cyclic voltammetry techniques. The response characteristics of cyclic voltammetry and square wave voltammetry showed a remarkable increase in the anodic peak current and electrochemical impedance spectroscopy revealed a lowering in charge transfer resistance at the boron-doped diamond electrode as compared to the glassy carbon electrode that can be attributed to the higher sensitivity of boron-doped diamond sensor. Cyclic voltammetry at the boron-doped diamond surface revealed the oxidation of wedelolactone with two oxidation peaks $\left(\mathrm{P}_{1}\right.$ and $\left.\mathrm{P}_{2}\right)$ with $\mathrm{Ep}_{1}=0.4 \mathrm{~V}$ and $\mathrm{Ep}_{2}=1.00 \mathrm{~V}$ with scan rate varying from $10-220 \mathrm{mV} / \mathrm{s}$ and exhibits diffusion-controlled process. Based on the electrochemical measurements, a probable oxidation mechanism has been deduced and the electrode dynamics parameters have been evaluated. The effect of concentration on the peak currents of wedelolactone was found to have a linear relationship within the concentration range of 50-700 ng/mL. The LOD and LOQ were found to be 43.87 and $132.93 \mathrm{ng} / \mathrm{mL}$ respectively. The applicability of the proposed method was further scrutinized by the successful determination of wedelolactone in real plant samples.
\end{abstract}

Keywords. Wedelolactone; boron-doped diamond electrode; impedance; voltammetry.

\section{Introduction}

Herbs are considered as the storehouse of various secondary metabolites having pharmacological potentials and their chemical partnership leads to favourable synergistic or additive effects with minimum side effects. Their bioactive principles tend to normalize physiological function and provide rational means for the treatment of many obstinate and incurable diseases. ${ }^{1-3}$

Wedelolactone (WDL), 7-Methoxy-5, 11, 12-trihydroxycoumestan, (scheme 1) forms the major constituent of the traditional medicinal plant Eclipta alba Hassk. (Asteracea), which is a perennial herb grown throughout India and Southwestern U.S, in moist and damp land. ${ }^{4,5}$ The literature reveals that WDL is known to show anti-HIV activity against HIV-1 integrase (IN), exhibiting high inhibitory effect, and possesses a wide range of biological activities and therapeutic properties. ${ }^{6-11}$ It was further found to suppress caspase11 which plays an important role in regulating apoptosis by inhibiting IKK complex. ${ }^{12}$ These reasons fasten the development of an efficient and reliable analytical method for the quantification of WDL.

\footnotetext{
*For correspondence
}

Different analytical methods have been explored for the estimation and quantification of WDL which includes HPLC, ${ }^{13-15}$ HPTLC, ${ }^{16,17}$ UV spectrophotometry, ${ }^{18}$ ICP-MS analysis, IR, EPR.${ }^{19}$ However, these methods are time consuming and involve derivatization steps prior to the final analysis. Apart from this, the aforementioned procedures involve excess amount of solvents, reagents and sophisticated instrumentation. On the other hand, electrochemical techniques are easy to use, highly sensitive, inexpensive, and provide quick response. Its application includes determination of redox properties of chemical constituents which provides insights into their metabolic fate and in vivo redox processes. ${ }^{20-30}$ An extensive literature survey revealed that the electrochemical investigation has so far not been reported for the study of the redox behaviour of WDL.

Boron-doped diamond electrode (BDDE) has been the subject of considerable interest as an electrode material for various electroanalytical applications, as it is more advantageous over the traditionally employed electrodes (e.g., glassy carbon electrode or the platinum electrode). ${ }^{31-37}$ This is because of its very wide potential window (upto $3 \mathrm{~V}$ ) in aqueous solutions, low background currents, resistance to thermal shock, extreme electrochemical stability and corrosion 


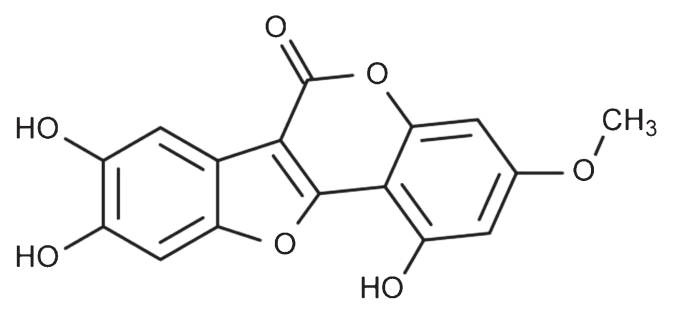

Scheme 1. Chemical structure of wedelolactone.

resistant towards aggressive media. ${ }^{38-41}$ Moreover boron has low charge carrier activation energy of $0.37 \mathrm{eV},{ }^{42}$ as a consequence of which it is by far the most widely used dopant to produce conducting diamond electrodes. Boron doping leads to a p-type semiconductor. ${ }^{43}$

The present work reports a new and explicit electrochemical method for the study of WDL by square wave voltammetry (SWV) and cyclic voltammetry (CV) at BDDE, using Britton-Robinson buffer $(\mathrm{pH} 2.5)$ as a supporting electrolyte. BDDE unveiled the mechanistic aspects of the phytoconstituent in the solution system. Electrochemical impedance spectroscopy (EIS) was employed to scrutinize the charge transfer resistance of the BDDE and GCE detailing higher sensitivity of the boron-doped diamond sensor as compared to the GCE. This method was further successfully employed for the investigation of WDL in plant samples.

\section{Experimental}

\subsection{Instrumentation}

All electrochemical studies were performed at a PC-controlled AUTOLAB PGSTAT 302N (EcoChemie B.V., Utrecht, The Netherlands) potentiostatgalvanostat with IME663 and software NOVA 1.8. EIS was carried out using FRA 2 module. A standard three electrode electrochemical assembly was used in the study that contained BDDE and GCE as the working electrode, platinum wire as counter and $\mathrm{Ag} / \mathrm{AgCl}(3 \mathrm{M} \mathrm{KCl})$ as reference electrode that were fitted in one compartment cell, connected with electrochemical workstation through Metrohm 663VA stand. The electrochemical cell was fitted with the nitrogen gas bubbler. All $\mathrm{pH}$ measurements were made on a Mettler Toledo $\mathrm{pH}$ meter fitted with a glass electrode and a $\mathrm{Ag} / \mathrm{AgCl}$ electrode as reference which was pre-standardized with buffers of known $\mathrm{pH}$. All measurements were carried out at room temperature.

\subsection{Materials and reagents}

WDL standard $(\geq 99 \%)$ was obtained from the Sigma Aldrich. Ultra-pure water (Milli-Q water with resistivity $18 \mathrm{M} \Omega . \mathrm{cm}$ ) was obtained from ELGA purification system (U.K.). Standard solution of WDL ( $1 \mathrm{mg} / \mathrm{mL}$ ) was prepared by dissolving pure compound in methanol and was further diluted with brittonrobinson buffer to get the concentration in the working range. To investigate WDL in real samples, plant of Eclipta alba (authenticated by Department of Botany, Dayalbagh Educational Institute, Agra) was purchased from commercial source. Solutions at all the stages of the study were prepared by using analytical grade reagents and were used without further purification.

\subsection{Working analytical procedure}

BDDE and GCE were polished against the alumina slurry (particle size $0.01 \mu \mathrm{m}-0.3 \mu \mathrm{m}$ ) spread over the Buehler cloth, and copiously rinsed with deionized water followed by gently blowing under the nitrogen stream to remove the residual alumina particles. After this mechanical treatment, electrodes were electrochemically activated against a suitable electrolyte by applying a potential of $+1.3 \mathrm{~V}$ for $30 \mathrm{sec}$.

The stock solution of WDL $(1 \mathrm{mg} / \mathrm{mL})$ was prepared in methanol. Working solutions were prepared by further dilution with the supporting electrolyte to get the desired concentration range. Initially, a series of britton-robinson buffer ( $\mathrm{pH}$ 2.5-12) were prepared in ultrapure water and used as supporting electrolytes. About $10 \mathrm{~mL}$ of electrolyte solution containing appropriate amount of standard WDL or sample was added to the electrolytic cell. Prior to all the electrochemical measurements, all the solutions were purged with the pure $\mathrm{N}_{2}$ gas to remove the interference due to $\mathrm{O}_{2}$. Then the electrodes were immersed and the voltammograms were recorded within the potential window of 0 to $1.4 \mathrm{~V}$. Electrochemical impedance measurements were performed in the solution of $5 \mathrm{mM} \mathrm{K}_{3} \mathrm{Fe}(\mathrm{CN})_{6}$ in $0.1 \mathrm{M}$ phosphate buffer solution (PBS) by applying the AC voltage with $10 \mathrm{mV}$ amplitude in a frequency range from $0.1 \mathrm{~Hz}$ to $1000 \mathrm{~Hz}$. The results were plotted in the form of Nyquist plots. All voltammetric measurements were carried out at ambient temperature.

\section{Results and Discussions}

\subsection{Electrochemical behaviour of WDL at BDDE and $G C E$}

Electrochemical behaviour of WDL at BDDE and at the GCE was investigated by $\mathrm{CV}$ and SWV techniques. Figure 1 (A and B) represents the $\mathrm{CV}$ and SWV of WDL at the GCE (b) and at BDDE (c). At each of the 

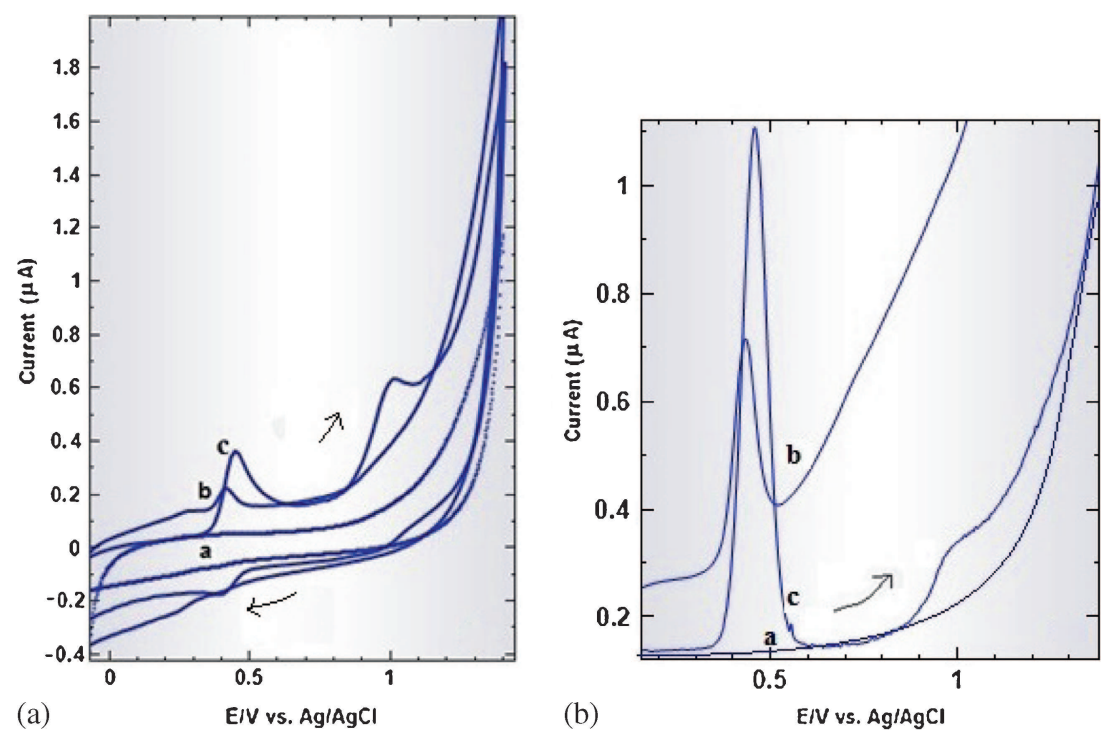

Figure 1. Square wave voltammogram (B, amplitude: $20 \mathrm{mV}$, frequency: $25 \mathrm{~Hz}$, step potential: $5 \mathrm{mV}$, scan rate: $125 \mathrm{mV} / \mathrm{s}$ ) and Cyclic voltammogram (A, scan rate $70 \mathrm{mV} / \mathrm{s}$ ) comparing the peak potential and current values of WDL obtained at b) GCE and c) BDDE, a) blank in BR buffer $\mathrm{pH} 2.5$ at a concentration of $500 \mathrm{ng} / \mathrm{mL}$ and $700 \mathrm{ng} / \mathrm{mL}$ respectively.

electrodes, WDL exhibited two oxidation peaks that can be ascribed owing to the presence of functional $-\mathrm{OH}$ groups attached to ring structures.

The working surface area of the BDDE and the GCE were obtained by the $\mathrm{CV}$ using $1 \mathrm{mM} \mathrm{K}_{3} \mathrm{Fe}(\mathrm{CN})_{6}$ as a redox probe at different scan rate. The surface area can be calculated using Randles-Sevcik equation $\left(298^{\circ} \mathrm{K}\right)$ as follows ${ }^{44}$

$$
\mathrm{Ip}=\left(2.69 \times 10^{5}\right) \mathrm{n}^{3 / 2} \mathrm{~A} \mathrm{C}_{0} \mathrm{D}^{1 / 2} v^{1 / 2}
$$

For $\mathrm{K}_{3} \mathrm{Fe}(\mathrm{CN})_{6}, \mathrm{n}=1$ and $\mathrm{D}=7.6 \times 10^{-6} \mathrm{~cm}^{2} / \mathrm{s}$. From slope of Ip $(\mu \mathrm{A})$ vs. $v^{1 / 2}$ the area were determined to be $0.069 \mathrm{~cm}^{2}$ for the BDDE and $0.028 \mathrm{~cm}^{2}$ for the GCE electrodes. Thus, the current values for BDDE and GCE were observed to be $4.34 \mu \mathrm{A} / \mathrm{cm}^{2}$ and 3.52 $\mu \mathrm{A} / \mathrm{cm}^{2}$ for $\mathrm{CV}, 14.49 \mu \mathrm{A} / \mathrm{cm}^{2}$ and $12.49 \mu \mathrm{A} / \mathrm{cm}^{2}$ for SWV.

\subsection{Electrochemical Impedance Spectroscopy}

The increase in the electron transfer at the BDDE was investigated using electrochemical impedance spectroscopy technique. For this AC amplitude of $10 \mathrm{mV}$ at a frequency of $0.1-100 \mathrm{kHz}$ was applied. The higher electrocatalytic behaviour of BDDE was confirmed by the reduction in the charge transfer resistance (figure 2A). The values observed for the charge transfer resistance, $\mathrm{R}_{\mathrm{CT}}$, fitting an appropriate equivalent circuit, were determined and found to be $174 \mathrm{k} \Omega / \mathrm{cm}^{2}$ at BDDE and $643 \mathrm{k} \Omega / \mathrm{cm}^{2}$ at GCE (figure 2B).
The electrical equivalent circuit compatible with the Nyquist plots comprises of $R_{S}$ the solution resistance, $\mathrm{Q}_{\mathrm{dl}}$ the double layer capacitance, $\mathrm{R}_{\mathrm{CT}}$ the charge

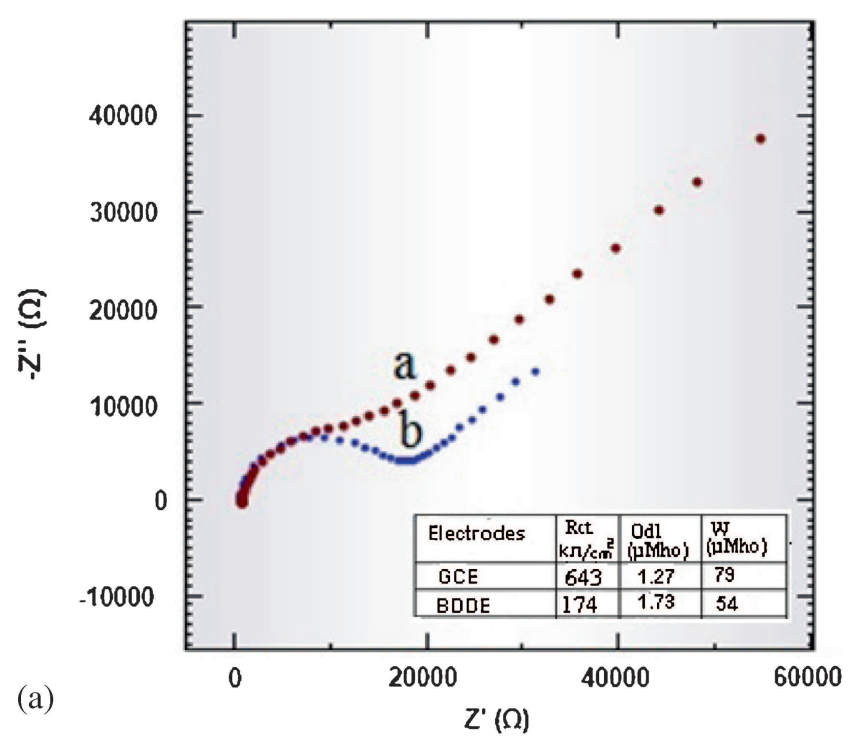

(b)

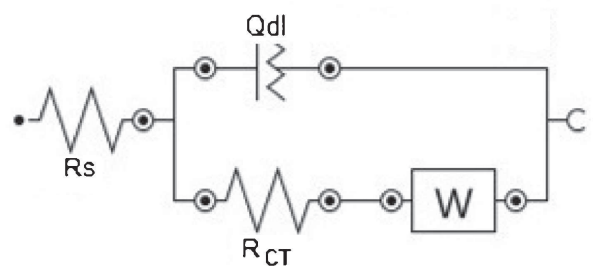

Figure 2. Nyquist plots of $5 \mathrm{mM} \mathrm{K}_{3} \mathrm{Fe}(\mathrm{CN})_{6}$ in $0.1 \mathrm{M}$ PBS at $\operatorname{BDDE}(\mathrm{A}, \mathrm{a}), \operatorname{GCE}(\mathrm{A}, \mathrm{b})$, and corresponding equivalent circuit (B). 
transfer resistance and $\mathrm{W}$ the Warburg impedance. The semi-circle observed in the Nyquist plot reveals the lower charge transfer resistance at BDDE surface as compared to GCE which can be attributed to the higher sensitivity of the electrochemical sensor. A constant phase element was used instead of the pure capacitance because of the electrode surface inhomogeneities. ${ }^{45}$

\subsection{Effect of scan rates}

To study the effect of scan rate on the oxidation peak of WDL, voltammograms were recorded for different scan rate from $10-220 \mathrm{mV} / \mathrm{s}$ at a fixed concentration $(700$ $\mathrm{ng} / \mathrm{mL}$ ) of WDL at BDDE. The information involving electrochemical mechanism can be obtained from the investigation of the response characteristics of $\mathrm{CV}$ on the electrooxidation process of WDL (figure 3). A linear relationship was obtained between the peak current intensity (Ip; $\mathrm{P}_{1}$ and $\mathrm{P}_{2}$ anodic peak currents) and the square root of scan rate $(v)^{1 / 2}$, suggesting the diffusion controlled process at the electrode surface. The linear relationship between Ip and $(v)^{1 / 2}$ for $\mathrm{P}_{1}$ follows $\operatorname{Ip}(\mu)=0.043(\nu)^{1 / 2}-0.111, R^{2}=0.991$ and for $P_{2}$, $\operatorname{Ip}(\mu \mathrm{A})=0.025(v)^{1 / 2}-0.085, \mathrm{R}^{2}=0.989$. The results

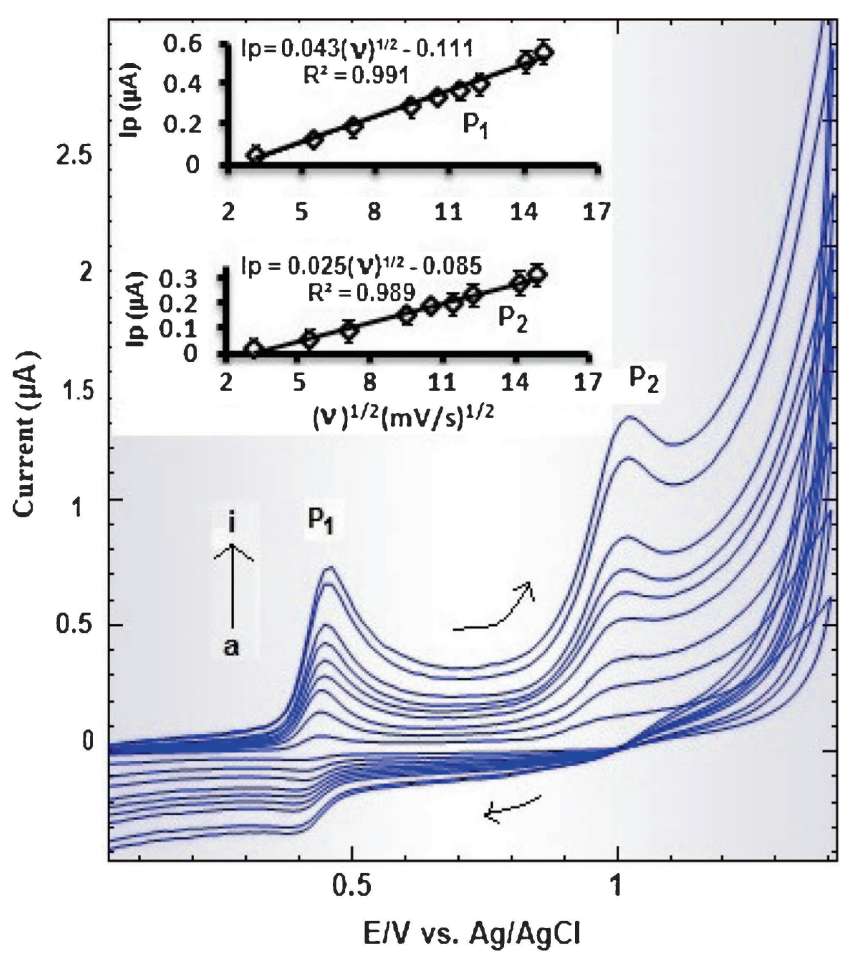

Figure 3. Cyclic voltammograms of WDL (700 ng/mL in Brittton-Robinson buffer $2.5 \mathrm{pH}$ ) at scan rates 10-220 $\mathrm{mV} / \mathrm{sec}(10,30,50,90,110,130,150,200$ and $220 \mathrm{mV} / \mathrm{s}$, curves a $-\mathrm{i}$ respectively) and Inset figure represent plots of $(v)^{1 / 2}$ vs. Ip for $\mathrm{P}_{1}$ and $\mathrm{P}_{2}$. confirms the electroxidation diffusion controlled process of WDL.

Moreover, from the literature, ${ }^{46}$ for an anodic reaction, the relationship between $\mathrm{E}_{\mathrm{p}}$ and $v$ can be described as:

$$
\begin{aligned}
\mathrm{E}_{\mathrm{p}}= & \mathrm{E}^{\circ}+\mathrm{RT} / \alpha \mathrm{n} \mathrm{F}\left[0.780+\ln \left(D^{1 / 2} / k_{s}\right)\right. \\
& \left.+\ln (\alpha \mathrm{nF} v / \mathrm{RT})^{1 / 2}\right]
\end{aligned}
$$

Where $\mathrm{E}^{\circ}$ is the formal redox potential, $\mathrm{R}$ and $\mathrm{F}$ values are $8.314 \mathrm{~J} / \mathrm{K}$.mol and $96480 \mathrm{C} / \mathrm{mol}$ respectively, $\mathrm{k}_{\mathrm{s}}$ is the standard heterogeneous rate constant, $\alpha$ is the charge transfer coefficient and D is the diffusion coefficient.

From the slope of the straight line of $E_{p}$ against $\ln v, \alpha$ n was calculated to be 0.46 and 0.89 for $\mathrm{P}_{1}$ and $\mathrm{P}_{2}$ respectively. For a diffusion-controlled anodic behaviour, assuming $\alpha$ to be $0.5,{ }^{47}$ number of electrons participating (n) during the oxidation process of WDL was calculated to be one for the anodic peak $\mathrm{P}_{1}$ and two for the anodic peak $\mathrm{P}_{2}$.

\subsection{Effect of supporting electrolyte and its $\mathrm{pH}$}

To achieve the optimum electrolyte, the influence of various supporting electrolytes such as $\mathrm{KCl}$, phosphate buffer, acetate buffer and Britton-Robinson buffer on the electrooxidation of WDL $(700 \mathrm{ng} / \mathrm{mL})$ was investigated. Britton-Robinson buffer was chosen as the optimum buffer with respect to the fairly well defined current responses and prominent peak shape. The effect of $\mathrm{pH}$ on the oxidation of WDL was examined over the $\mathrm{pH}$ range (2.5-12). The anodic peak currents $\left(\mathrm{P}_{1}\right.$ and $\left.\mathrm{P}_{2}\right)$ and the peak potential for the oxidation of WDL were found to be sensitive towards the $\mathrm{pH}$ of the solution. It was observed that the current values $\left(\mathrm{I}_{\mathrm{p}}\right)$ for anodic peaks $\mathrm{P}_{1}$ and $\mathrm{P}_{2}$ started to decrease with the increase in $\mathrm{pH}$ values and at higher $\mathrm{pH}(\mathrm{pH}>7.9)$, the peak current almost disappeared (figure 4A). Thereby considering the sensitivity and the peak shape, $\mathrm{pH} 2.5$ was selected as the optimum $\mathrm{pH}$ for the entire electrochemical measurement. Moreover there was a sequential shift of the anodic peak potential with the augmentation of solution $\mathrm{pH}$, indicating that the protons had participated in the electrode reaction process of WDL. ${ }^{48,49}$ Figure $4 \mathrm{~B}$ explains the shifting of peak potential with the increase in $\mathrm{pH}$ values following the linear equation $\mathrm{Ep}(\mathrm{mV})=$ 700.3-88.05pH, $\mathrm{R}^{2}=0.961\left(\mathrm{P}_{1}\right)$ and $\mathrm{Ep}(\mathrm{mV})=$ $1092-45.64 \mathrm{pH}, \mathrm{R}^{2}=0.964\left(\mathrm{P}_{2}\right)$. Furthermore, the peak potential and the $\mathrm{pH}$ of the solutions can be expressed by the following Nernst equation. ${ }^{50}$

$$
\mathrm{E}_{\mathrm{p}}=\mathrm{E}^{\circ \prime}-2.303 \mathrm{RTm} \mathrm{pH} /(1-\alpha) \mathrm{nF}
$$




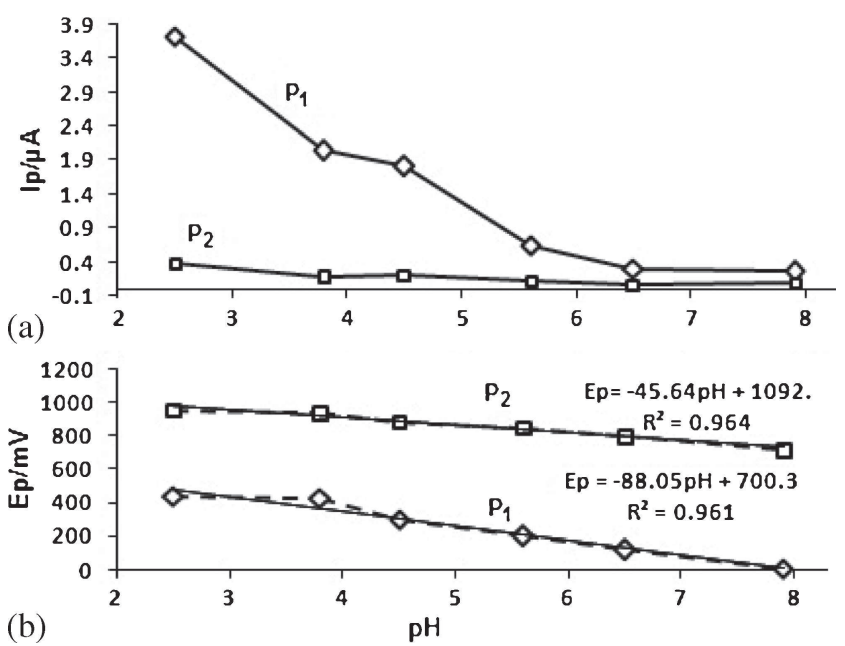

Figure 4. Dependence of peak current (Ip, A) and peak potential $(\mathrm{Ep}, \mathrm{B})$ of WDL $(700 \mathrm{ng} / \mathrm{mL})$ on the $\mathrm{pH}(2.5-7.9)$ of supporting electrolyte (Brittton-Robinson buffer).

where ' $\mathrm{m}$ ' is the number of protons participating in the electrode reaction. Thus, from the slope of $E_{p} v s$. $\mathrm{pH}$ and the aforementioned Nernst equation ' $\mathrm{m}$ ' was calculated to be one.

\subsection{Probable oxidation mechanism of WDL}

The voltammetric techniques can be utilized to elucidate the electroactivity and possible reaction mechanism of various compounds. Here in the present case, $\mathrm{CV}$ and SWV of WDL exhibited two anodic voltammetric peaks $\left(\mathrm{P}_{1}\right.$ and $\left.\mathrm{P}_{2}\right)$, which can be attributed to the presence of phenol and dihydroxy moieties respectively. According to Corduneanu et al. ${ }^{51}$ and Janeiro et $a .^{52}$ resorcinol group is found to be less electroactive than phenolic group, suggesting that the oxidative peak $\mathrm{P}_{1}$ appearing at lower potential corresponds to the phenol moiety whereas the peak $\mathrm{P}_{2}$ appearing at higher corresponds to the dihydroxy group. Thus based on all the electrochemical measurements, one electron-proton transfer is observed in each step with a total of two proton-electron coupled reaction and a possible oxidation mechanism of WDL has been proposed as shown in scheme 2.

\subsection{Calibration curve and detection limit}

Under the optimized condition, response characteristics of SWV exhibited a linear relationship between the peak current values and the concentration of WDL within the range $50 \mathrm{ng} / \mathrm{mL}$ to $700 \mathrm{ng} / \mathrm{mL}$ (figure 5). The calibration plot of Ip (A) vs. concentration $(\mathrm{ng} / \mathrm{mL})$ can be described by the equations Ip $(\mathrm{A})=0.017(\mathrm{ng} / \mathrm{mL})$ $+1.366 ; \mathrm{R}^{2}=0.994\left(\mathrm{P}_{1}\right)$ and $\mathrm{Ip}(\mathrm{A})=0.003(\mathrm{ng} / \mathrm{mL})-$ $0.686 ; \mathrm{R}^{2}=0.991\left(\mathrm{P}_{2}\right)$

Limit of detection (LOD) and limit of quantification (LOQ) (estimated as $3 \mathrm{~S} / \mathrm{m}$ and $10 \mathrm{~S} / \mathrm{m}$, respectively, ' $\mathrm{S}$ ' being the standard deviation and ' $\mathrm{m}$ ' being the slope of the calibration curve) were obtained as $43.87 \mathrm{ng} / \mathrm{mL}$ and $132.93 \mathrm{ng} / \mathrm{mL}$. Various statistical parameters for the linear regression equation have been evaluated and reported in table 1.

Further to explore the analytical application and the specificity of the proposed method, the effect of some common excipients (such as glucose, sucrose and lactose) were studied by analyzing sample solution of WDL $(100 \mathrm{ng} / \mathrm{mL})$ spiked with varying concentration of each excipients under the optimized conditions. The determination of WDL in the presence of above- mentioned excipients was evaluated and a recovery range from $98.03 \%$ to $99.18 \%$ was obtained. Thus, the results<smiles>COc1cc(O)c2c(c1)oc(=O)c1c3cc(O)c(O)cc3oc21</smiles><smiles>COc1cc(O)c2c(c1)oc(=O)c1c3cc(O)c(O)cc3oc21</smiles><smiles>COc1cc(O)c2c(c1)oc(=O)c1c3cc(O)c([O-])cc3oc21</smiles>

Scheme 2. Proposed oxidation mechanism for WDL. 


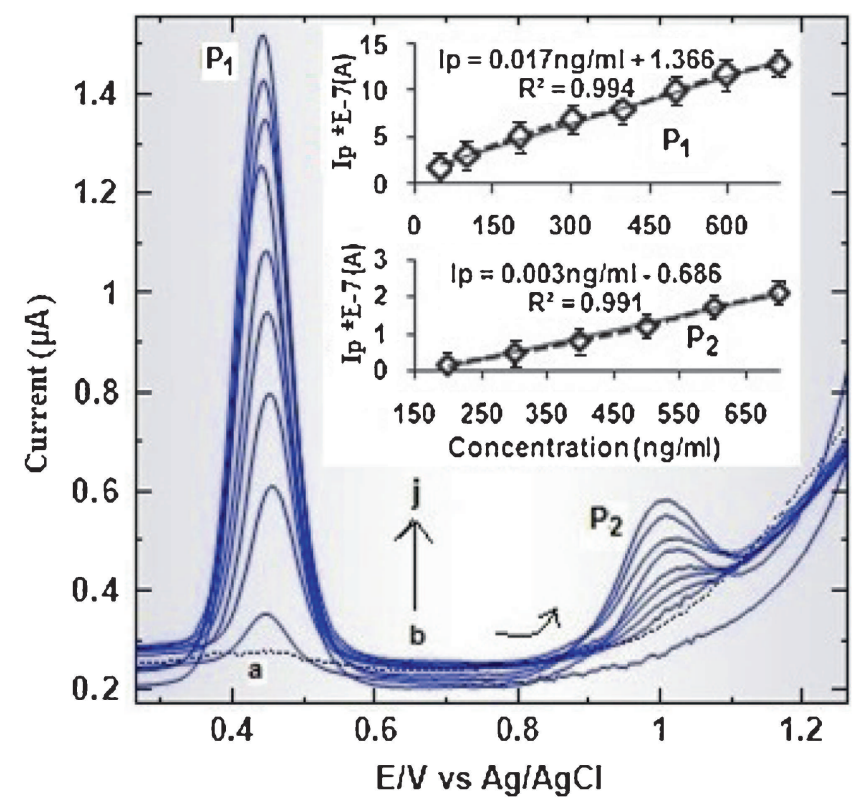

Figure 5. Square wave voltammograms of WDL at different concentration levels, (50 ng/mL-700 ng/mL, b-j), blank (curve a) and Inset figure represents plot of concentration vs. current Ip for $\mathrm{P}_{1}(50,100,200,300,400,500,600$ and $700 \mathrm{ng} / \mathrm{mL})$ and $\mathrm{P}_{2}(200-700 \mathrm{ng} / \mathrm{mL})$.

showed that there was no serious interferences occurred from the classical additives.

\subsection{Determination of WDL in plant sample (Eclipta alba)}

Isolation of the plant extract was attained by percolation of the methanol ( $48 \mathrm{~h}$ ) through the bed of herbaceous material at room temperature to produce an extract having active principles contained in the herbaceous material. Before adding the solvent, plant material was washed, dried at room temperature and grinded to powder form. Then $5 \mathrm{~g}$ of the dried plant material was weighed and soaked in $100 \mathrm{~mL}$ of solvent. Lustrous

Table 1. Square-wave voltammetric method validation parameters for standard linearity.

\begin{tabular}{lc}
\hline Linearity parameters & Results \\
\hline Slope & 0.0174 \\
Standard deviation & 0.0005 \\
Intercept & 1.3660 \\
Standard deviation & 0.2278 \\
Correlation coefficient & 0.994 \\
Standard error of estimation & 0.3385 \\
Sum of squares of regression & 113.6899 \\
Sum of squares of residuals & 0.6875 \\
Limit of detection $\left(\mathrm{ng} \mathrm{mL} \mathrm{mL}^{-1}\right)$ & 43.87 \\
Limit of quantification $\left(\mathrm{ng} \mathrm{mL}^{-1}\right)$ & 132.93 \\
\hline
\end{tabular}

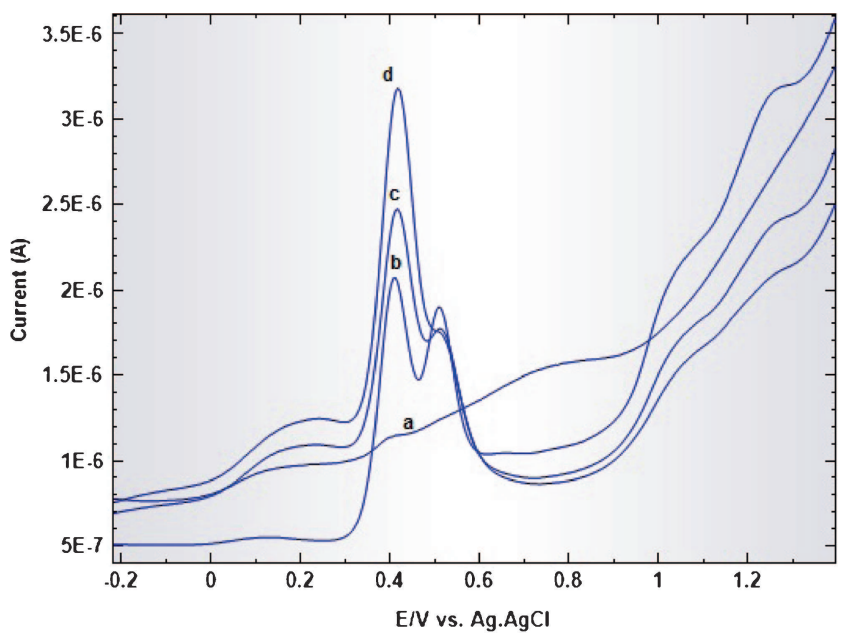

Figure 6. (a) Square wave voltammograms of $100 \mu \mathrm{l}$ of plant extract; (b) and standard WDL additions 50ng/mL (c); $100 \mathrm{ng} / \mathrm{mL}$ (d) with blank (curve a).

plant extract was obtained which was highly concentrated and contains a large proportion of the active principles, which can be used in lower unit doses for analytical experiments. The appropriate amount of the extract was taken in the voltammetric cell containing the supporting electrolyte and voltammogram was recorded (figure 6). In order to validate the veracity, WDL standard solution was added into the sample solution for recovery detection. The results are listed in table 2 . The assay results indicate that the proposed voltammetric method can be applied for determination of WDL in plant extract effectively. The concentration of the unknown phytoconstituent (WDL) can be determined using the standard addition method by the following equation: ${ }^{53}$

$$
\mathrm{C}_{\mathrm{u}}=\mathrm{I}_{\mathrm{p} 1} \mathrm{C}_{\mathrm{s}} \mathrm{V}_{\mathrm{s}} /\left[\mathrm{I}_{\mathrm{p} 2}\left(\mathrm{~V}_{\mathrm{u}}+\mathrm{V}_{\mathrm{s}}\right)\right]-\mathrm{I}_{\mathrm{p} 1} \mathrm{~V}_{\mathrm{u}}
$$

After getting the voltammogram of the supporting electrolyte, known volume $\left(\mathrm{V}_{\mathrm{u}}\right)$ of unknown concentration $\left(\mathrm{C}_{\mathrm{u}}\right)$ of the investigated herbal drug is added and the resulting voltammogram is recorded and peak current $\left(I_{p 1}\right)$ is measured, then the known volume $\left(V_{s}\right)$ of known concentration $\left(\mathrm{C}_{\mathrm{s}}\right)$ of standard pure drug is

Table 2. Analytical results for WDL in Eclipta alba samples.

Standard added Standard found* (\%) Accuracy ${ }^{\mathrm{a}}$ (\%) RSD $(\mathrm{ng} / \mathrm{mL}) \quad(\mathrm{ng} / \mathrm{mL})$

\begin{tabular}{lccc}
\hline 100 & 99.5 & 99.5 & 0.20 \\
200 & 198.3 & 99.15 & 0.19 \\
300 & 296.7 & 98.9 & 0.22
\end{tabular}

${ }^{\mathrm{a}}$ [standard found/standard added] $\times 100$

*Amount found represents the average of six observations $(n=6)$. 
Table 3. Comparison of the detection limit of the present work with other methods.

\begin{tabular}{lcc}
\hline Method & $\begin{array}{c}\text { Limit of detection/ } \\
\text { quantification }\end{array}$ & Reference \\
\hline HPLC-PDA & $2 \mu \mathrm{g} / \mathrm{mL}$ & 54 \\
HPLC & $2.5 \mu \mathrm{g} / \mathrm{ml}$ & 55 \\
Electroanal. Quant. (BDDE) & $43.8 \mathrm{ng} / \mathrm{mL}$ & Present work
\end{tabular}

Abbreviations: HPLC-PDA, performance liquid chromatography-photo diode array; HPLC, high performance liquid chromatography; Electroanal. Quant., electroanalytical quantification; BDDE, boron doped diamond electrode.

added and peak current $\left(\mathrm{I}_{\mathrm{p} 2}\right)$ is measured. The amount of WDL content was found to contain $0.30 \%$ in the plant Eclipta alba.

\subsection{Comparison of the sensitivity of the present work with other reported methods}

Detection limit of the proposed method is compared with the other reported methods. ${ }^{54,55}$ Table 3 reveals that the present method is more sensitive and the detection limit of WDL is lower than check the reported methods.

\section{Conclusions}

A new method for the selective determination of WDL in Britton-Robinson buffer ( $\mathrm{pH} 2.5$ ) at BDDE has been presented in this paper. BDDE offered high sensitivity towards WDL and found to be appropriate and effective for the selective determination of the solution system. The sensitivity of the electrodes can be explained on the basis of electrochemical impedance spectra against the ferricyanide solution with lower charge transfer resistance at BDDE as compared to GCE. The voltammetric study of WDL at different scan rates revealed diffusion controlled reaction process. Electrode process dynamics parameters have been evaluated and based on this a plausible reaction mechanism has been deduced. The calibration plot reveals linearity within the range of 50-700 ng/mL with a correlation coefficient of 0.994 for $\mathrm{P}_{1}$ and 0.991 for $\mathrm{P}_{2}$. The lower limit of detection $(43.87 \mathrm{ng} / \mathrm{mL})$ proved the sensitivity of the proposed method and the method was successfully employed for the determination of WDL in a real plant sample.

\section{Acknowledgements}

The authors acknowledge the Ministry of Human Resource Development project, Dayalbagh Educational
Institute, Dayalbagh, Agra, India, for providing financial assistance under an NMEICT project. They are also thankful to UGC for providing fellowship to two of the authors (Sachin Saxena and Ratnanjali Shrivastava).

\section{References}

1. Murray M T and Pizzorno J E 1999 In Textbook of Natural Medicine (China: Churchill Living)

2. Matsuse I T, Lim Y A, Hattori M, Correa M and Gupta M P 1999 J. Ethnopharmacol. 6415

3. Rajabhandari M, Wegner U, Julich M, Schopke T and Mental R 2001 J. Ethnopharmacol. 74251

4. Uniyal R C, Sandhu S and Chandok J K 1998 In Herbology: The Ayurvedic Encyclopedia (India: Sri Sadguru Publications) pp. 77-88

5. Kirtikar K R and Basu B D 1998 In Indian Medicinal Plants 2nd ed., (India: International Book Distributors) pp. 1360-1361

6. Tewtrakul S, Subhadhirasakul S, Cheenpracha $\mathrm{S}$ and Karalai C 2007 Phytother. Res. 211092

7. Saxena A K, Singh B and Anand K K 1993 J. Ethnopharmacol. $\mathbf{4 0} 155$

8. Singh B, Saxena A K, Chandan B K, Agarwal S G, Bhatia M S and Anand K K 1993 Phytother. Res. 7154

9. Singh B, Saxena A K, Chandan B K, Agarwal S G and Anand K K 2001 Indian J. Pharmacol. 45435

10. Simonsen H T, Nordskjold J B, Smitt U W, Nyman U, Palpu P, Joshi P and Varughese G 2001 J. Ethnopharmacol. 74195

11. Thakur V D and Mengi S A 2005 J. Ethnopharmacol. 10223

12. Kobori M, Yang Z, Gong D, Heissmeyer V, Zhu H, Jung Y K, Angelica M, Gakidis M, Rao A, Sekine T, Kegami F I, Yuan C and Yuan J 2004 Cell Death Differ. 11123

13. Hamrapurkar P, Chachad P and Phale M 2009 Natural Products: An Indian Journal 557

14. Wagner H, Geyer B, Kiso Y, Hikino $\mathrm{H}$ and Rao G S 1986 Planta Med. 52370

15. Murali B, Amit A, Anand M S and Samiulla D S 2002 J. Nat. Remedies. 299

16. Thorat R M, Jhadhav V M, Kadam V J, Kamble S S and Salaskar K P 2009 Int. J. Chem. Tech. Res. 11079

17. Patel M B, Kadakia V M and Mishra S H 2008 Indian J. Pharm. Sci. 70689

18. Das N, Bhavsar G C and Chauhan M G 1990 Indian Drugs $\mathbf{2 8} 100$

19. Reddy S L, Fayazuddin M D, Ahmad A and Reddy G S 2008 Spectrochim. Acta. $\mathbf{7 1} 31$

20. Tsopelas F, Petropoulou M O, Zikos N, Spyropoulou E, Andreadou I and Kakoulidou A T 2011 J. Solid State Electrochem. 151099

21. Saxena S, Shrivastava R and Satsangee S P 2012 Maced. J. Chem. Chem. Eng. 31195

22. Yan J, Wang W, Chen L and Chen S 2008 Colloid Surf. B. 67205

23. Teradal N L, Kalanur S S, Prashanth S N and Seetharamappa J 2012 J. Appl. Electrochem. 42917

24. Jain R, Radhapyari K and Jadon N 2007 J. Colloid Interface Sci. 314572

25. Jain R, Gupta V K, Jadon N and Radhapyari K 2010 Anal. Biochem. 40779 
26. Jain R, Mishra R and Diwedi A 2009 J. Sci. Ind. Res. 68 540

27. Jain R and Yadav R K 2011 Drug Test Anal. 3171

28. Jain R and Yadav V 2011 Colloid Surf., B. 88729

29. Raj K R, Sharma S, Saxena S, Shrivastava M M and Satsangee S P 2010 E-J. Chem. 7169

30. Jain R, Dwivedi A and Mishra R 2009 J. Hazard. Mater. 169667

31. Peckova K, Musilova J, Barek J and Zima J 2008 In Progress on drinking water research $\mathrm{M} \mathrm{H}$ Lefebvre and M M Roux (Eds.) (New York: Nova Sci. Pub) p. 103

32. Souza C D, Braga O C, Vieira I C and Spinelli A 2008 Sens. Actuators, B. 13566

33. Gumustas M and Ozkan S A 2010 Anal. Bioanal. Chem. 397189

34. Deimkova H, Scampicchio M, Zima J, Barek J and Mannino S 2009 Electroanalysis 211014

35. Peckova K, Musilova J and Barek J 2009 Crit. Rev. Ana. Chem. 39148

36. Santos K D, Braga O C, Vieira I C and Spinelli A 2010 Talanta 801999

37. Sartori E R, Medeiros R A, Rocha-Filho R C and Fatibello-Filho O 2010 Talanta 811418

38. Bozal B and Uslu B 2010 Comb. Chem. High Throughput Screening. 13599

39. Peleskov Y V 2002 Russ. J. Electrochem. 381275

40. Panizza M and Cerisola G 2005 Electrochim. Acta. 51 191
41. Alfaro M A Q, Ferro S, Martínez-Huitle C A and Vong Y M 2006 J. Braz. Chem. Soc. 17227

42. Haenni W, Rychen P, Fryda M and Comninellis C 2004 In Thin-film diamond Part B Ch. Nebel (Ed.) Semiconductors and Semimetals series (Academic Press, Elsevier) p. 149

43. Kraft A 2007 Int. J. Electrochem. Sci 2355

44. Liu L Q, Xiao F, Li J W, Wu W B, Zhao F Q and Zheng B Z 2008 Electroanalysis 201194

45. Tabeshnia M, Heli H, Jabbari A and Movahedi A A M 2010 Turk. J. Chem. 3435

46. Laviron E 1974 J. Electroanal. Chem. 52355

47. Xing T L, Wang F, Mao Y Y, Wang L P and Ye B X 2009 J. Chin. Chem. Soci. 56303

48. Yang S, Yang R, Li G, Li J and Qu L 2010 J. Chem. Sci. 122919

49. Dar R A, Brahman P K, Tiwari S and Pitre K S 2011 J. App. Electrochem. 411311

50. Erk N 2004 Anal. Bioanal. Chem. 3781351

51. Corduneanu O, Janeiro P and Brett A M O 2006 Electroanalysis 18757

52. Janeiro P and Brett A M O 2004 Anal. Chim. Acta. 518 109

53. Ewing G W 1995 In Instrumental methods of chemical analysis 5th edition (Philadelphia: Lippincott- Raven) p. 465

54. Kumar S and Dhanani T 2013 Braz. J. Pharm. Sci. 4957

55. Patil A A, Sachin B S, Wakte P S and Shinde D B J. Adv. Res. 4479 